\title{
Response of Faba Bean (Vicia faba L.) to Phosphorus Fertiliizer and Farm Yard Manure on Acidic Soil in High Land of Tembaro Woreda, Southern Ethiopia
}

\author{
Tadele Buraka \\ Assistant professor in soil science, WCU \\ Daniel Manore \\ Lecturer in agronomy, WCU) \\ Alemu lealago \\ $\mathrm{PhD}$ in soil science, WSU
}

\begin{abstract}
Faba bean (Vicia faba L.) variety was evaluated for its performance upon the application of P (TSP) fertilizers and Farm yard manure in Tembaro Woreda of Kembata Tembaro Zone in 2016 cropping season. This study was carried out with the objectives of investigating the optimum rates of $P$ fertilizers $(0,15,30,45$ and $60 \mathrm{~kg} / \mathrm{ha})$ and $\operatorname{FYM}(0,4$ and $8 \mathrm{t} / \mathrm{ha})$ for faba bean production on acidic soils. The experiment was laid out in factorial RCBD design with three replications. The data collected were plant height, tillers per plant (productive \& Nonproductive), Pods per plant, Seeds per pod, grain yield, biomass and hundred seed weight. In the analysis of variance some of the parameters such as tillers per plant, Seeds per pod, pods per plants, total biological yield and grain yield showed significance difference $(p<0.05,0.01,0.001)$. In the mean comparison analysis for significant parameters, the FYM with the rate of 4 and $8 \mathrm{t} /$ ha combined with $60 \mathrm{~kg} / \mathrm{ha} \mathrm{P}$ fertilizer performed better than that other combinations. Application of FYM modified after harvesting the soil chemical properties such Soil $\mathrm{P}^{\mathrm{H}}$, TN(\%), Av.P(ppm), OM \% and CEC (meq/100g) showed variation before sowing 5.21, 0.43, 6.7, 5.7 and 24 , after harvesting $6.31,0.39,8.2,7.8$ and 32 ,respectively and soil physical properties such as particle size distribution, water holding capacity, bulk density and soil porosity. Soil water holding capacity showed variability at Tembaro site before sowing $(\mathrm{FC}=34, \mathrm{PWP}=20, \mathrm{WHC}=14)$ and after harvesting $(\mathrm{FC}=44, \mathrm{PWP}=23$, $\mathrm{WHC}=21)$. The soil acidity changed from strongly acidic to moderately acidic after harvesting.
\end{abstract}

Keywords:- Farmyard manure, Triple superphosphate, treatments, replication

DOI: $10.7176 / \mathrm{JBAH} / 9-1-04$

\section{INTRODUCTION}

Faba bean (Vicia faba L.) is among the major grain food legumes cultivated in different part of Ethiopia including Kembata Tembaro zone(CSA, 2013). Broad beans have a long tradition of cultivation in Old World agriculture, being among the most ancient plants in cultivation and also among the easiest to grow. They are still often grown as a cover crop to prevent erosion, because they can overwinter and because as a legume, they fix nitrogen in the soil. These commonly cultivated plants can be attacked by fungal diseases, such as rust (Uromyces viciae-fabae) and chocolate spot (Botrytis fabae). They are also attacked by the black bean aphid (Aphis fabae).

Organic matter such as compost application is also affordable and less risky soil nutrient management practices which sustains cropping system through better nutrient recycling, improved soil structure and water holding capacity (Makind, 2007; Adejumo et al., 2010). Tiwari et al. (2002) also elucidated that application of $\mathrm{OM}$ in fertilization schedule improved OC

status and available N, P, K and S in soils which sustain its health. Similarly, significant improvements were observed in soil total N, OC, available P and CEC by using organic amendments (World Bank, 1995). Ezekiel (2010) also reported that OM increases available moisture content of soils, moderates soil acidification, improves soil bulk density, increase buffering capacity against drastic change in $\mathrm{pH}$, complexing $\mathrm{Al}^{3+}$ and thereby reducing its toxicity, improves soil aeration and beneficial microbial activities as well as CEC of the soil. Zhihui et al. (2007) also indicated that compared to the control, longterm application of high amount of FYM increased $\mathrm{OC}$, total $\mathrm{N}$ and $\mathrm{S}$ contents by 63, 50 and 37\%, respectively. Furthermore, low soil OM content has been implicated for poor soil structure, low $\mathrm{N}$ availability, poor soil aeration and high soil compaction (María et al., 2014). Thus the productivity of this crop is constrained by low soil $\mathrm{P}^{\mathrm{H}}$ associated with low $\mathrm{P}$ availability. Acid soils occur widely in the highlands of Ethiopia where the rainfall intensity is high and the land has been under cultivation for many years. These soils have PH values of less than 5.5, which result in low faba bean yields compared to other faba bean growing areas of the country. Application of FYM at any rate improved the soil properties reduced the bulk density, soil $\mathrm{pH}, \mathrm{EC}$ and Soluble ions of $\mathrm{Na}^{+}, \mathrm{HCO}^{3-}$ and $\mathrm{Cl}^{-}$. 
Objective of the study

To find out the effects of farm yard manure and $\mathrm{P}$ fertilizer on the yield and yield components

To determine the optimum rates of $\mathrm{P}$ fertilizer and FYM for faba bean production

\section{MATERIALS AND METHODS}

\subsection{Description of the Study Area}

The study in two sites are located at Tembaro woreda in Kembata Tembaro zone, southern Ethiopia. The research site is found in the altitude ranging between 2300-2800 m.a.s.l, at $380 \mathrm{~km}$ from Addis Ababa and the average annual rainfall of $1850 \mathrm{~mm}$.

\subsection{Treatments and experimental design}

A study was undertaken on the effects five levels of $\mathrm{P}$ fertilizer and three level of air dried decomposed farmyard manure on growth, yield and yield components of faba bean.

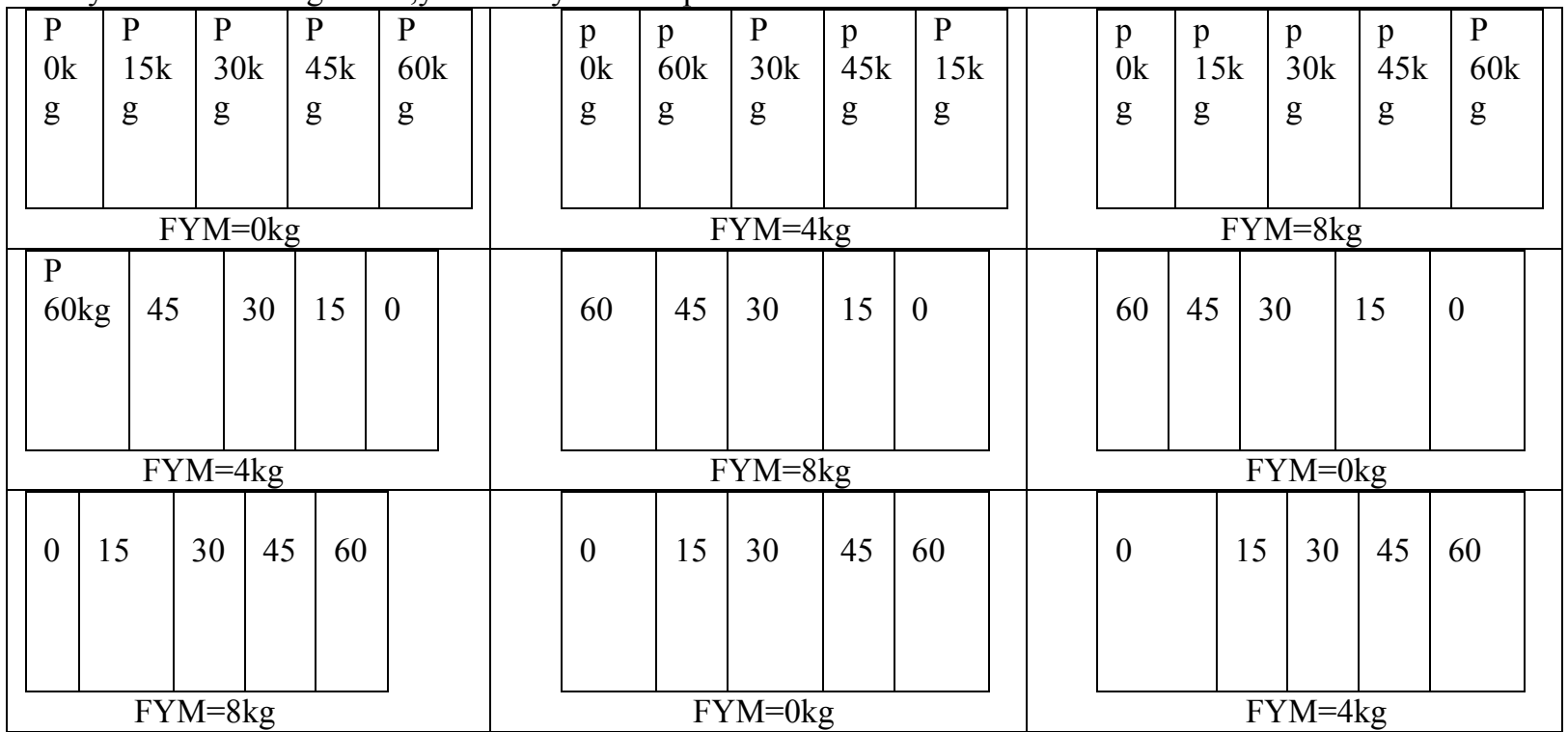

Faba bean

$\mathrm{B} / \mathrm{n}$ row $=40 \mathrm{~cm}, 2 . \mathrm{B} / \mathrm{n}$ plant $=10 \mathrm{~cm}, 3 . \mathrm{B} / \mathrm{n}$ plot $=50 \mathrm{~cm}, 4 . \mathrm{B} / \mathrm{n}$ block $=1.5 \mathrm{~m}$ to $2 \mathrm{~m}$

The $\mathrm{P}$ fertilizer was applied at the rate of $0,15,30,45$ and $60 \mathrm{~kg}$ ha-1 in the form of triple superphosphate (TSP). FYM was applied at the rate of 0,4 and 8 tha $^{-1}$. The faba bean cultivar was used CS 20DK. The experiment was conducted in a RCBD factorial designed with three replications. FYM was kept under shade from two to three months until its decomposition.

The decomposed manure was applied 21-30 days before sowing and mixed thoroughly in the upper 15-20 $\mathrm{cm}$ soil depth. During application, the moisture content of the FYM will be $24 \%$. The phosphorus was applied along with seeds as triple superphosphate. Twenty two $\mathrm{kg} \mathrm{N} \mathrm{ha}^{-1}$ was applied as a starter dressing to all plots in the form of urea. In all replications, planting was done from 21 to 23 June at the seed rate of $200 \mathrm{~kg}$ ha- 1 on a plot size of $2.6 \mathrm{~m} \times 2.6 \mathrm{~m}$. All other cultural practices were followed as per the recommendation.

\subsection{Soil sample analysis}

Composite soil samples were collected before planting and after harvesting from $15-20 \mathrm{~cm}$ soil depth from each replication. They were then analyzed from for BD, FC,PWP, WHC, Soil porosity, particle size distribution, $\mathrm{pH}$, $\mathrm{P}, \mathrm{N}, \mathrm{OC}$, and CEC. Soil $\mathrm{pH}$ was measured in 1:1 soil: water suspension. The standard kjeeldhal method was used for soil nitrogen determination. Available $\mathrm{p}$ was determined using Bray-II method. The cation exchange capacity of the soil was determined using ammonium acetate method. Similarly, farm yard manure samples were analyzed for $\mathrm{P}^{\mathrm{H}}, \mathrm{P}, \mathrm{N}, \mathrm{OC}$, and CEC using the same analytical procedures used for soil analysis.

\subsection{Agronomic data collection and analysis}

Agronomic data such as stand count, plant height, number of pods per plant and seeds per pod total above ground biological and seed yields, harvest index (HI) and 1000-seed weight were recorded. To estimate total biological and seed yields, the whole plot size $\left(2.6 \times 2.6 \mathrm{~m}^{2}\right)$ was harvested and threshed manually. Seed yield was adjusted to $10 \%$ moisture content. Analyses of variance for all data were performed using the SAS statistical package program version 8.2 (SAS Institute Inc., 2001). In the case of significant differences between treatments, least significant differences (LSD) at 5\% probability level were used to establish the difference among the means. 
Correlation analyses were made between seed yield and yield components. Since data were not homogenous, mean results of each cropping season were reported.

\subsection{Economic analysis}

Economic analysis was performed to investigate the economic feasibility of the treatment. Partial budget, dominance and marginal analyses was used. The market prices of phosphate fertilizer and FYM were used for analyses. The phosphorus content of the FYM will be converted into equivalent price of phosphorus fertilizer.

\section{RESULT ANALYSIS AND INTERPRETATION}

Composite soil samples were collected from experimental site before sowing and after harvesting from $15-30 \mathrm{~cm}$ soil depth from each replication. The experimental sites were Tembaro site.

3.1. Composite soil and FYM test analysis before sowing and after harvesting Tembaro site The soil samples were analyzed for Soil Texture in Tembaro site varied that before sowing (Sand=21\%, Silt $=41 \%$ and Clay $=38 \%$ ) which was clay loam class and after harvesting (Sand $=23 \%$, Silt $=46 \%$ and Clay $=31 \%$ ) which was silty clay loam as soil textural triangle combination(Table 1). The soil textural class both before sowing and after harvesting was showed that is favorable soil type for faba bean growth.

Soil water holding capacity showed variability at Tembaro site before sowing $(\mathrm{FC}=34, \mathrm{PWP}=20, \mathrm{WHC}=14)$ and after harvesting $(\mathrm{FC}=44, \mathrm{PWP}=23, \mathrm{WHC}=21)$ were presented (Table 1). According to rating Beernaert (1990), available water content values in the Tembaro site in both before sowing and after harvesting were rated as high. This reveal that in general, the higher the percentage of silt and clay sized particles, the higher the water holding capacity. The small particles (clay and silt) have a much larger surface area than the larger sand particles. This large surface area allows the soil to hold a greater quantity of water. The amount of organic material in a soil also influences the water holding capacity. As the level of organic matter increases in a soil, the water holding capacity also increases, due to the affinity of organic matter for water.

Soil Bulk density showed variation before sowing and after harvesting in Tembaro site from $1.33 \mathrm{~g} \mathrm{~cm}^{-3}$ to $1.17 \mathrm{~g} \mathrm{~cm}^{-3}$, respectively (Table 1). According to Hillel, (1980), bulk densities range for agricultural soils from values of the order of $1 \mathrm{~g} \mathrm{~cm}^{-3}$ to $1.7 \mathrm{~g} \mathrm{~cm}^{-3}$. This divulges that the bulk density of study sites was within good range for agriculture and that no excessive compaction and no restriction to root development.

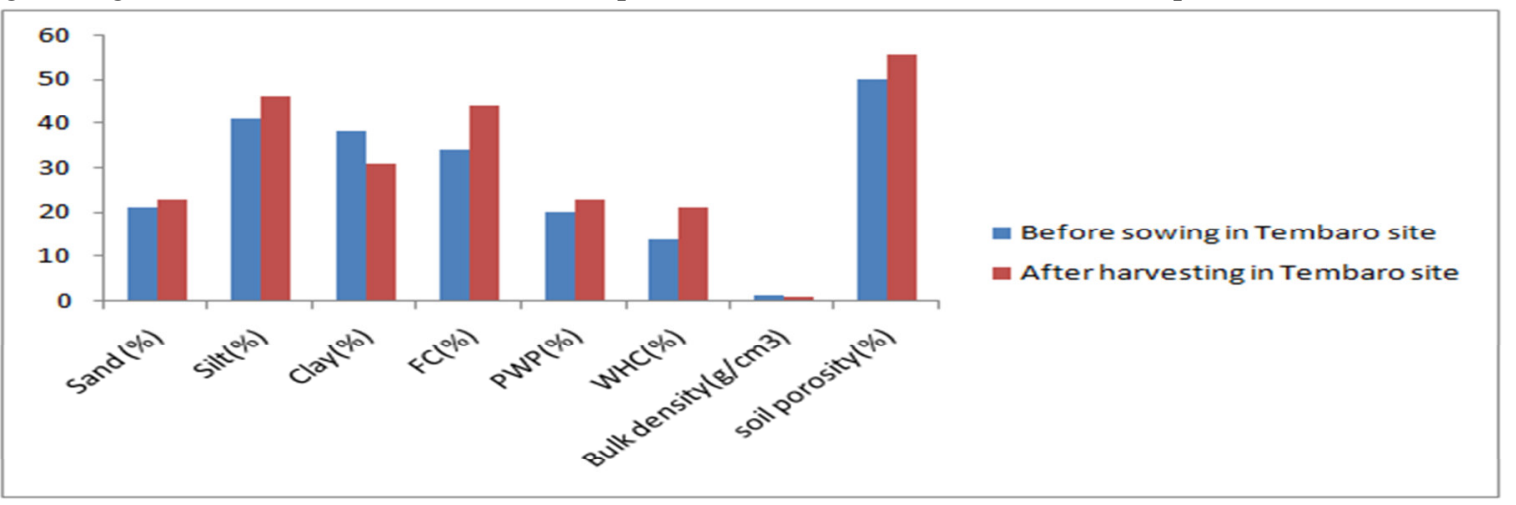

Fig 1 . Tembaro Site Soil Physical properties

Soil porosity varied before sowing and after harvesting at Tembaro site from $49.8 \%$ to $55.6 \%$ which were presented in the Table 1. According to Brady and Weil (2002), ideal total pore space values, which are acceptable for crop production, are around $50 \%$. This reveals that the total porosity of the study site soil was acceptable for crop production with its good aeration, water movement, microbial activity and root penetration. This reveals that the soil porosity was affected directly by soil organic matter.

Table 1. Soil physical properties analysis (Tembaro site)

\begin{tabular}{|l|l|l|l|l|l|l|l|l|l|l|}
\hline & Parameters & \multicolumn{3}{|l|}{ Soil particle size distribution } & \multicolumn{2}{l|}{$\begin{array}{l}\text { Soil water holding } \\
\text { capacity }\end{array}$} & $\begin{array}{l}\text { Bulk } \\
\text { density } \\
\left(\mathrm{g} / \mathrm{cm}^{3}\right)\end{array}$ & $\begin{array}{l}\text { Soil } \\
\text { porosity } \\
(\%)\end{array}$ \\
\cline { 2 - 11 } & & $\begin{array}{l}\text { Sand } \\
(\%)\end{array}$ & $\begin{array}{l}\text { Silt } \\
(\%)\end{array}$ & $\begin{array}{l}\text { Clay } \\
(\%)\end{array}$ & $\begin{array}{l}\text { Combination } \\
\text { class }\end{array}$ & $\begin{array}{l}\text { FC } \\
(\%)\end{array}$ & $\begin{array}{l}\text { PWP } \\
(\%)\end{array}$ & $\begin{array}{l}\text { WHC } \\
(\%)\end{array}$ & \\
\hline $\begin{array}{l}\text { Tembaro } \\
\text { site }\end{array}$ & $\begin{array}{l}\text { Before } \\
\text { sowing }\end{array}$ & 21 & 41 & 38 & Clay loam & 34 & 20 & 14 & 1.33 & 49.8 \\
\cline { 2 - 11 } & $\begin{array}{l}\text { After } \\
\text { harvesting }\end{array}$ & 23 & 46 & 31 & $\begin{array}{l}\text { Silty clay } \\
\text { loam }\end{array}$ & 44 & 23 & 21 & 1.17 & 55.6 \\
\hline
\end{tabular}

$\mathrm{FC}=$ field capacity, $\mathrm{PWP}=$ permanent wilting point, $\mathrm{WHC}=$ soil water holding capacity 
All of the soil samples were analyzed for Soil $\mathrm{P}^{\mathrm{H}}$, TN(\%), Av.P(ppm), OM \% and CEC (meq/100g) parameters with values of Tembaro site soil test showed variation before sowing 5.21, 0.43, 6.7, 5.7 and 24, after harvesting $6.31,0.39,8.2,7.8$ and 32 respectively, which were presented in the Table 2. According to Ethiosis team analysis, (2014), the rating of soil $\mathrm{P}^{\mathrm{H}}$ was strongly acidic before sowing and moderately acidic after harvesting in Tembaro site. According to Marschner (1995), soils with pH values of less than 5.5 are deficient in $\mathrm{Ca}$ and/or Mg as well as P. According to Churchman et al., (1983), these values reveal the absence of calcium carbonate in the study area, where values of $\mathrm{pH}-\mathrm{H}_{2} \mathrm{O}$ less than 6.5 are generally considered as noncalcareous or the soil was not affected by salt. Currently, it is estimated that about $40 \%$ of arable lands of Ethiopia are affected by soil acidity/ $\mathrm{Al}^{3+}$ toxicity (Taye, 2007). The soil $\mathrm{P}^{\mathrm{H}}$ values in both study sites were showed that strongly acidic soil before sowing and application of FYM but as the result of $\mathrm{P}^{\mathrm{H}}$ values showed in both study sites after harvesting and application of FYM were modified the soil acidity from strongly acidic to moderately acidic. This divulges that the soil acidity can be modified by application of organic fertilizers such as FYM

The soil samples were analyzed for soil $\mathrm{TN}(\%)$ parameters with values of Tembaro site soil test before sowing and after harvesting 0.43 and 0.39 , respectively, which were presented in the Table 2 . According to (Havlin et al. 1999 and Ethiosis team analysis, 2014), TN content of soils in Tembaro sites were categorized under the optimum level after harvesting and high level before sowing. This indicates that organic matter is the main sources of nitrogen, thus the need to maintain the organic matter content through organic matter management methods, such as incorporating crop residues to the soil, is important. The results are in accordance with the findings of (Wakene and Heluf, 2003 and Tuma 2007) who reported that intensive and continuous cultivation forced oxidation of $\mathrm{OC}$ and thus resulted in reduction of TN. As revealed the result of soil test in TN content was reduced from before sowing to after harvesting in study site due to intensive and continuous cultivation, leaching and crop removal.

The soil samples were analyzed for soil av.P(ppm) parameters with values of Tembaro site soil test before sowing and after harvesting 6.7 and 8.2, respectively, which were presented in the Table 2. As reported in Ethiosis team analysis, (2014), the soil av.P(ppm) value was rated very low in Tembaro site. In tropical soils, large quantities of soil P in mineral form are not readily available for absorption by the plant (Barber, 1984). This phosphorus occurs in numerous combinations with iron and aluminium in most of well weathered tropical soils, such as in the present study area. The phosphorus content in soil solution is low as compared to other nutrients such as nitrogen, potassium, calcium and magnesium (Tisdale et al., 1993). Many soils fix large quantity of phosphorus by converting readily soluble phosphorus to forms less available to plants in the above combinations (Miller et al., 1995). According to the ratings for some tropical soils (Olsen and Dean, 1965; Brook, 1983; Havlin et al., 1999), available P contents in the study sites were very low and low (soil indicates a crop response to $\mathrm{P}$ fertilizers) in the all plots of experiment. Topsoil phosphorus is usually greater than that in subsoil due to sorption of the added phosphorus and greater biological activity and accumulation of organic material in the former. However, soil phosphorus content varies with parent material, extent of pedogenesis, soil texture, and management factors such as rate and type of phosphorus applied and soil cultivation (Tekalign et al., 1988). The soil test was divulged that in the study site the soil av.P(ppm) value was increased after harvesting and application fo FYM.

Table 2. Soil chemical properties laboratory test result analysis (Tembaro site)

\begin{tabular}{|l|l|l|l|l|l|l|}
\hline Sites & Parameters & Soil $\mathrm{P}^{\mathrm{H}}$ & $\mathrm{TN}(\%)$ & Av.P(ppm) & OM \% & CEC (meq/100g) \\
\hline \multirow{2}{*}{ Tembaro site } & Before sowing & 5.21 & 0.43 & 6.7 & 5.7 & 22 \\
\cline { 2 - 8 } & After harvesting & 6.31 & 0.39 & 8.2 & 7.8 & 32 \\
\hline
\end{tabular}

All of the soil samples were analyzed for soil OM \% parameters with values of Tembaro site soil test before sowing and after harvesting 5.7 and 7.8 ,respectively, which were presented in the Table 2. According to (Brook, 1983; Landon, 1991; and Ethiosis team analysis, 2014), rating for soils of tropical and subtropical regions, organic matter content of the surface soil in the study site before sowing was in optimium level and after harvesting was high level respectively, in all experimental replicactions due to crop residue. The soil test was showed that the soil OM \% was increased after harvesting and application of FYM in both study site. The occurrence of high amount of $\mathrm{OM}$ in surface horizons are normally expected because live plant roots and microorganisms that release organic compounds are restricted to the upper surface of soils. Moreover, various none living carbonaceous materials including roots remaining after harvest and crop residues are constantly added to the upper surface. 


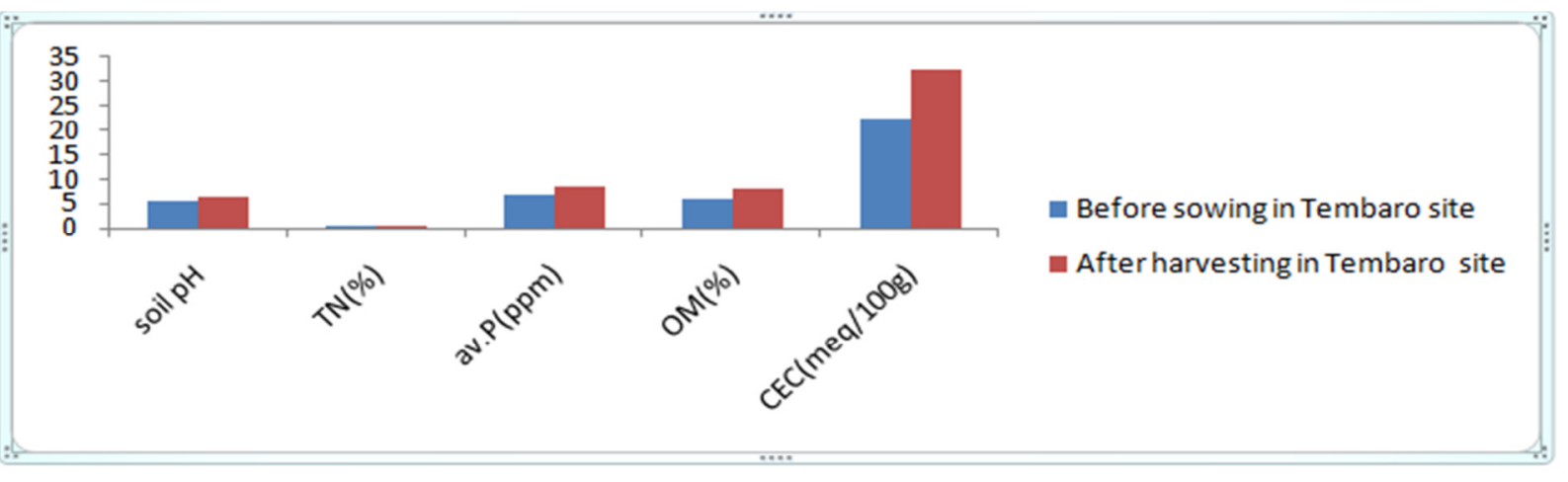

\section{Fig 2. Tembaro sites soil chemical properties graph}

All of the soil samples were analyzed for Soil CEC (meq/100g) parameters with values of Tembaro and Dunna sites soil test were showed before cropping and after cropping 22 and 32 and 24 and 29.6 respectively, which were presented in the Table 2. According to Brook (1983), the CEC of soil test in both study site was rated as medium before cropping and was rated as high after cropping, respectively. The soil test was showed that the CEC value in both study sites were increased after cropping and application of FYM.

Table 3. Farmyard manure laboratory analysis (Tembaro sites)

\begin{tabular}{|l|l|l|l|l|l|l|}
\hline Site & Parameters & $\mathrm{pH}$ & av.P $(\mathrm{ppm})$ & $\%$ OM & CEC & $\%$ TN \\
\hline Tembaro sites & Before sowing & 6.22 & 54.62 & 14.43 & 26.30 & 0.48 \\
\hline
\end{tabular}

Farm yard manure sample was analyzed for $\mathrm{pH}, \mathrm{P}, \mathrm{OM}, \mathrm{CEC}$ and TN, 6.22, 54.62, 14.43, 26.30 and 0.48 respectively using the same analytical procedures used for soil analysis (Table 3 ). The composite soil samples were collected after harvesting indicated that there were higher $\mathrm{pH}$ levels and nutrient concentrations on plots treated with both FYM and P fertilizer compared to sole application of either FYM or $\mathrm{p}$ fertilizer. The lowest $\mathrm{pH}$ and nutrient content were observed in soils, which were not treated with FYM. According to Sharma et al. (1990), the use of animal manure might have made the soil more porous and pulverized, allowing better root growth and development, thereby resulting in higher root cation exchange capacity. Sanchez (1976) has also indicated that the application of manure directly influences the availability of native or applied phosphorus. The soil chemical properties after harvesting higher than that of soil parameters before sowing the crop except TN. The results of this study indicated that FYM and phosphorus fertilizer positively influenced number of pods per plant and seeds per pod, total biological yield and seed yield of faba bean in all growing condition

\subsection{Crop data analysis and interpretation at Tembaro site \\ 3.2.1 Crop Phenology \\ 3.2.1.1 Days to Emergence}

Days of emergence was significantly influenced by FYM, while the TSP level effect did not significantly affect emergence of faba bean phosphorous level (Table 4). 8 tones and the control have early emergence which took 7 days. The 4 tones have late emergence which took 8 days (Table 4). Favorable moisture condition due to uniform rainfall distribution during planting contributed to smooth and even germination of faba bean during the season. The differences in seed germination could be due to the genotypic difference among phosphorous level and environmental factors as there is no effect of phosphorus level on the seed germination.

\subsubsection{Days to Flowering}

Data given in Table 4 indicated significant difference among farmyard manure as well as phosphorous level $(\mathrm{p}<0.05) .8$ tone ha-1 (101 days) took minimum days to flower, followed by 4 tone ha-1 (107). Phosphorous level was also varied in days of flowering. The time to flower appearance depends up on available nutrients, temperature and genetic makeup of the plant (Naidu et al. 1991).

\subsubsection{Days to Maturity}

Days to maturity were significantly varied among farm yard manure variation but not significantly influenced by phosphorous level (Table 4). 8 tone ha-1(123 days) took maximum days to mature, 4 tone ha-1 (112 days) took minimum days. Maturity of a crop depends up on photoperiod of genotypes, available nutrients, temperature and on the available moisture to the plant. This is also a varietal dependent character which is influenced by genetic variation of a variety (Reddy et al. 1991).

\subsubsection{Growth Parameters}

\subsubsection{Plant Height}

Significant difference was observed in both the phosphorous levels and farm yard manure in plant height faba bean (Table 4). Farm yard manure 8 tone ha- 1 and Phosphorous levels 45 and $60 \mathrm{~kg}$ ha-1 produced tallest plants, followed by $15 \mathrm{~kg}$ ha- 1 . Short stature plants were observed in 0 tone ha-1 farm yard manure and phosphorus 
levels 0 and $30 \mathrm{~kg}$ ha-1 which was statistically at par with (Table 4). This might be attributed to nutritional variation among phosphorous rate. This result agrees with the findings of Miah and Bhadra (1999) who reported variation on plant height among the growth parameters.

\subsubsection{Yield and Yield Components}

\subsubsection{Number of Pods per Plant}

Analysis of variance divulged that farm yard manure levels and phosphorous levels exerted significant influence on numbers of pods per plant (Table 4). 8 tone ha-1 had relatively higher number of pods per plant (30.6) while without farm yard manure had the lowest number of pods per plant. Similarly, $60 \mathrm{~kg}$ ha-1 phosphorus resulted in significantly large number of pods per plant (32.2) while small number of pods per plant (24.6) was recorded from with no fertilized plot. The result is in agreement with the work of Malik et al. (2006) and Dereje, (2007) who reported that increased number of pods per plant with B. japonicum appilication in soybean and phosphorous appilication. This increased pod number with applied phosphorous could be associated with enhanced growth and higher assimilate accumulation which is resulted due to better $\mathrm{N}$ nourishment from symbiotic $\mathrm{N}$ fixation.

\subsubsection{Number of Seeds per Pod}

The analysis of variance revealed that number of seeds per pod (NSPP) was significantly affected by phosphorous level and FYM. The highest NSPP (3.82) was recorded from the 8 tone ha-1 farm yard manure while the lowest NSPP (3.0) was from the 0 and 4 tone (Table 4). Similarly, the highest NSPP (4.2) was obtained from $60 \mathrm{~kg}$ ha-1 level of TSP fertilization, which was significantly superior to all other treatments, while the lowest NSPP (3.3) was recorded from strain $0 \mathrm{~kg}$ ha-1. The result showed that FYM played an important role in faba bean in promoting growth and thus resulting in a significant increase in the number of seeds per pod. This significant different of NSPP among FYM and phosphorous level were in line with the finding of Muhammad (2002) where appilication with Bradyrhizobium, and phosphorous not only increased the shoot growth, but also the NSPP.

Table 4: Effects of farm yard manure and Phosphorous fertilizer on phenology of faba bean at mid flowering at Tambaro Site

\begin{tabular}{|c|c|c|c|c|c|c|c|c|}
\hline \multicolumn{2}{|l|}{ Treatments } & $\begin{array}{l}\text { Days } \\
50 \% \\
\text { emergence }\end{array}$ & $\begin{array}{l}\text { Days } \\
50 \% \\
\text { flowering }\end{array}$ & $\begin{array}{l}\text { Plant } \\
\text { height } \\
\text { per plant }\end{array}$ & $\begin{array}{l}\text { Days to } \\
\text { physiological } \\
\text { maturity }\end{array}$ & $\begin{array}{l}\text { Tillers } \\
\text { per } \\
\text { plant }\end{array}$ & $\begin{array}{l}\text { Number } \\
\text { of pod } \\
\text { plant }\end{array}$ & $\begin{array}{l}\text { Seed per } \\
\text { pod }\end{array}$ \\
\hline FYM tone & 0 & $7.5 \mathrm{~A}$ & $108 \mathrm{~A}$ & 100.4 & $118 \mathrm{~B}$ & $2.8 \mathrm{~B}$ & $24.4 \mathrm{~B}$ & $3.1 \mathrm{~B}$ \\
\hline & 4 & $7.8 \mathrm{~B}$ & 107B & 104.5 & $112 \mathrm{~B}$ & $2.9 \mathrm{~B}$ & $29.8 \mathrm{BA}$ & $3.0 \mathrm{~B}$ \\
\hline & 8 & $7.4 \mathrm{~A}$ & 101B & 112 & $123 \mathrm{~A}$ & $3.0 \mathrm{~A}$ & $30.6 \mathrm{~A}$ & $3.82 \mathrm{~A}$ \\
\hline LSD (5\%) & & 0.46 & 1.2 & Ns & 1.89 & 0.27 & 0.92 & 0.32 \\
\hline$\underset{\mathrm{kg} / \mathrm{ha}}{\mathrm{TSP}}$ & 0 & 7.7 & $103 \mathrm{~B}$ & $94 \mathrm{~B}$ & 110 & $3.0 \mathrm{CB}$ & $22.4 \mathrm{D}$ & $3.3 \mathrm{~B}$ \\
\hline & 15 & 7.977 & 104B & $113 \mathrm{~B}$ & 112 & $3.1 \mathrm{~B}$ & $27 \mathrm{C}$ & $3.54 \mathrm{~B}$ \\
\hline & 30 & 8.0 & $105 \mathrm{BA}$ & $99.3 \mathrm{~B}$ & 115 & $2.99 \mathrm{~B}$ & $28.3 \mathrm{~B}$ & $3.4 \mathrm{~B}$ \\
\hline & 45 & 7.5 & 104BA & $116 \mathrm{~A}$ & 117 & $3.2 \mathrm{~A}$ & $31.4 \mathrm{~A}$ & $3.8 \mathrm{~A}$ \\
\hline & 60 & 7.6 & $106 \mathrm{~A}$ & $120 \mathrm{~A}$ & 121 & $3.1 \mathrm{~A}$ & $32.2 \mathrm{~A}$ & $4.2 \mathrm{~A}$ \\
\hline LSD (5\%) & & NS & 1.28 & 16.1 & NS & 0.31 & 1.06 & 0.33 \\
\hline CV\% & & 8.1 & 4.48 & 17.7 & 1.68 & 11.7 & 5.4 & 7.2 \\
\hline $\begin{array}{l}\text { Strains } \\
\text { varieties }\end{array}$ & * & NS & NS & NS & NS & NS & $*$ & NS \\
\hline
\end{tabular}

Mean values within column followed by the same letter are not significantly different $(\mathrm{p} \leq 0.05)$, NS $=$ non significant at $5 \%$ probability level, $n=45$ (Number of observation for each parameter)

\subsubsection{Hundred Seed Weight}

Analysis of variance of hundred seed weight (HSW) revealed that there was highly significant difference among the phosphorous level and FYM. There is also significance between in interactions (Table 5). Application with 4 and 8 tones ha-1 gave relatively higher seed weight, which is greater by $55.22 \%$ over the control treatment. Statistically significant variation in HSW was detected TSP level (Table 5). However, these treatments were significantly higher over the control or with no fertilizer. Similarly, phosphorous level displayed statistically significant variation among them in HSW where $15 \mathrm{~kg}$ ha-1 displayed the highest $(21.8 \mathrm{~g})$ followed by $60 \mathrm{~kg}$ ha1 (21.73) HSW. Previously, similar findings was reported by Aliet al etc. (2004) where P and FYM application brought a significant effect on HSW of chickpea. Kazemi et al. (2005) reported that soybean seed with phosphorous application significantly increased hundred seed weight. 


\subsubsection{Grain Yield}

Similar to all yield component parameters in the experiment, grain yield was also highly affected by application of FYM and phosphorous level (Table 4).The highest grain yield (26.90) kuntal ha-1 was recorded from application of 8 tone $\mathrm{kg}$ ha-1 followed by 4 tone $\mathrm{kg}$ ha-1.The lowest grain yield $\left(24.3 \mathrm{kuntal} \mathrm{ha}^{-1}\right)$ was recorded from control (Table 5). Similarly, the highest grain yield (26.87 kuntal ha-1) tone ha-1was recorded from phosphorous $60 \mathrm{~kg}$ ha- 1 followed by $45 \mathrm{~kg}$ and $30 \mathrm{~kg}$ ha-1. And statistically lowest grain yield (24.94 kuntal ha1) was recorded from the control fertilizer plot, (Table 5). The differences in grain yield among phosphorous level and FYM were attributable to the difference in number of seeds per pod and seed weight as it was also indicated by a significant positive correlation. A similar yield enhancing effect of TSP application on grain yield of soybean has also been reported by Abbasi et al. (2008) and Jat and Ahlawat( 2006).

\subsubsection{Total Biomass Yield}

FYM and phosphorous level had significant effects on the total biomass yield (Table 5). The highest total biomass yield $\left(5.81 \mathrm{t} \mathrm{ha}^{-1}\right)$ was obtained from application of 8 tons per ha and the lowest total biomass yield was recorded from application 0 tons per ha $\left(4.0 \mathrm{t} \mathrm{ha}^{-1}\right)$ (Table 5). Rate of phosphorus $60 \mathrm{~kg}$ ha-1 resulted in the highest total biomass yield $\left(5.5 \mathrm{t} \mathrm{ha}^{-1}\right)$ while the lowest total biomass yield $\left(4.0 \mathrm{tha}^{-1}\right)$ was recorded from no fertilizer application. Greater plant performances, also in yield and yield components resulted because of the $\mathrm{N}$ fixing and the positive role of the FYM. This is because of enough TSP provided from symbiotic N fixation and helps as energy source. Similar results has also been reported by Hayat et al. (2004) who found that rhizobium and TSP application increased the total biomass yield of mungbean and also Gharib et al. (2008) reported that developed root systems (due to P nutrition) increased water and nutrient uptake and consequently, increased photosynthesis and thus increase in total biomass yield.

Table 5: Effects of farm yard manure and Phosphorous fertilizer rate on phenology, yield and yield components of faba bean at Tambaro Site

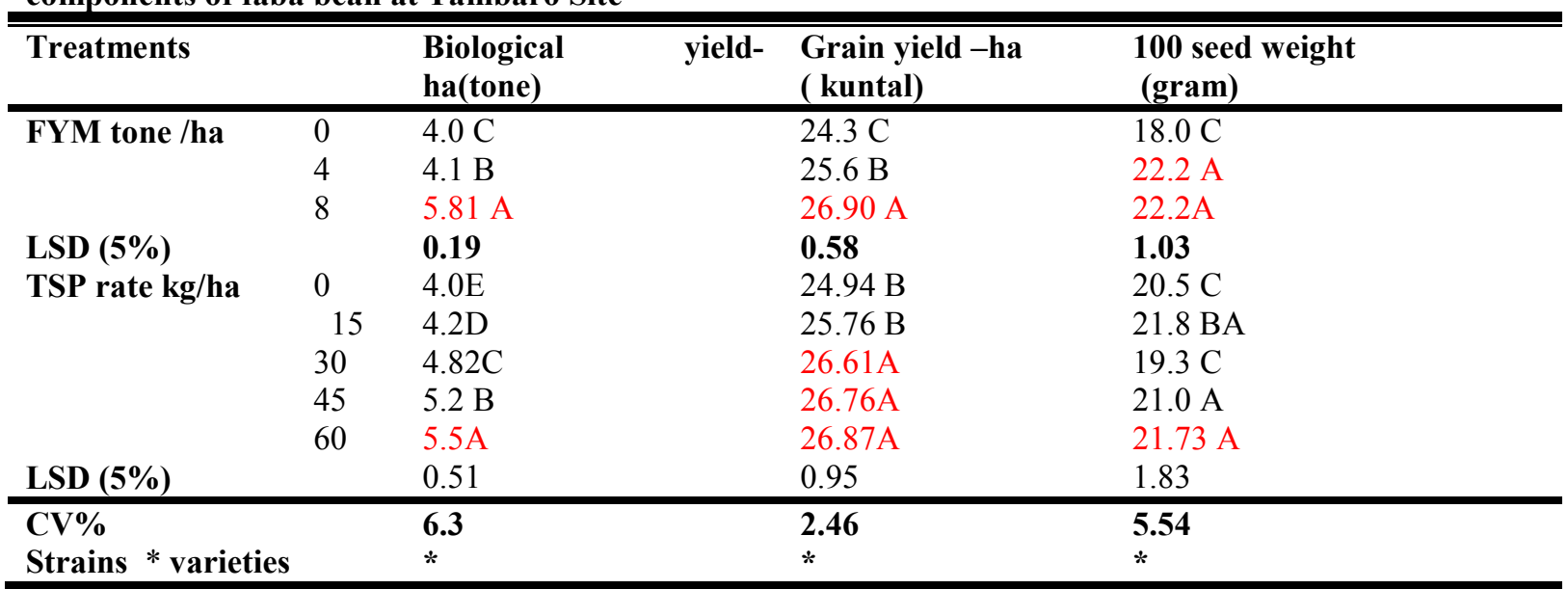

Mean values within column followed by the same letter are not significantly different $(\mathrm{p} \leq 0.05)$, NS $=$ non significant at $5 \%$ probability level, $\mathrm{n}=45$ (Number of observation for each parameter) $*$, **, $* * *=$ Significant at $5 \%, 1 \%$ and $0.1 \%$ probability level 

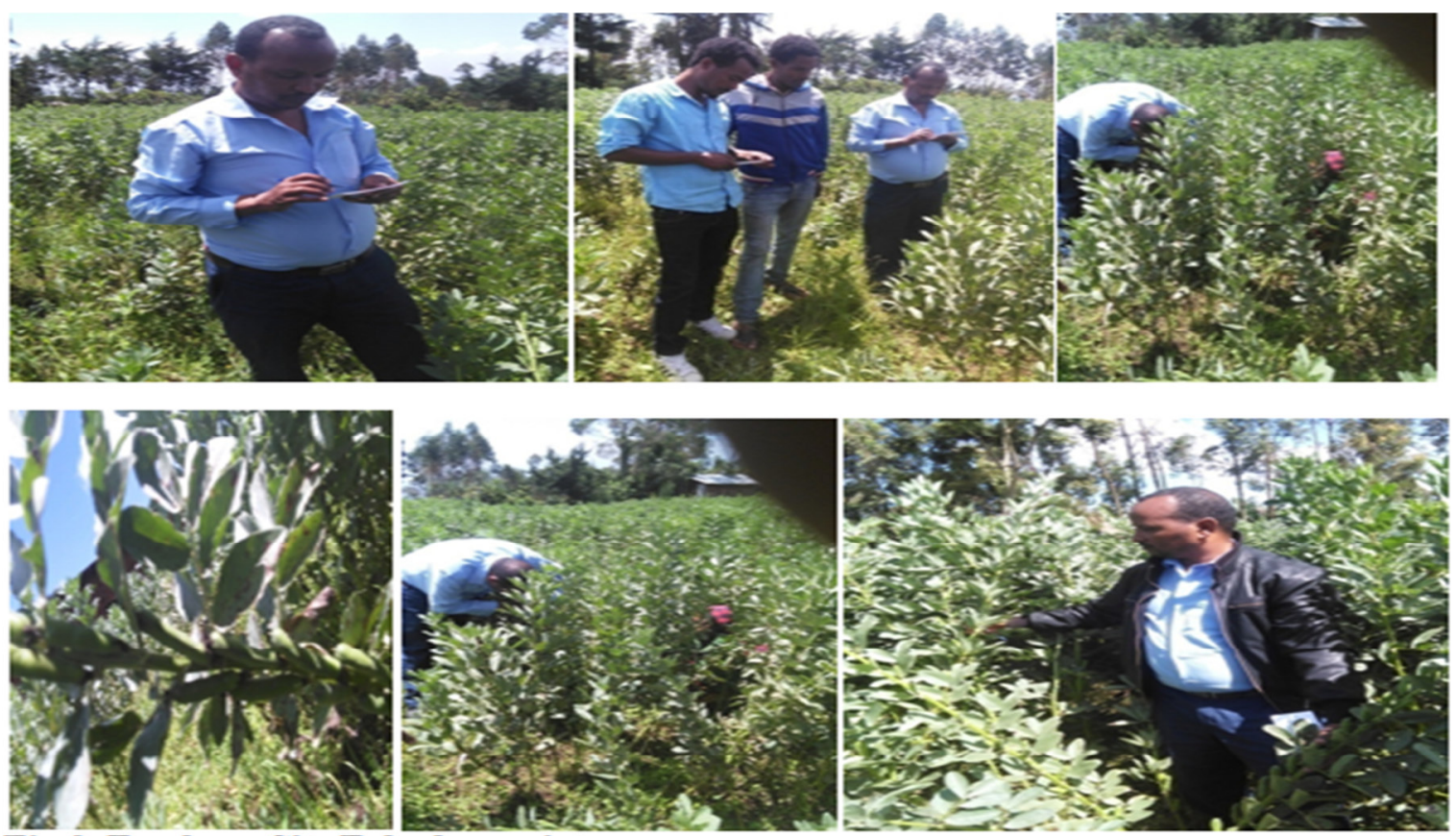

Fig. 3. Tembare Site Faba bean picture

\subsection{Economic Analysis}

Partial budget analysis of varied level farm yard manure and TSP fertilizer level on adjusted grain yield faba bean. Economics is the major criteria to evaluate the best treatments which were economically sound and which can be accepted by the farming community.

Table 3: Partial budget analysis of FYM and phosphorous fertilizer on adjusted yield of faba bean

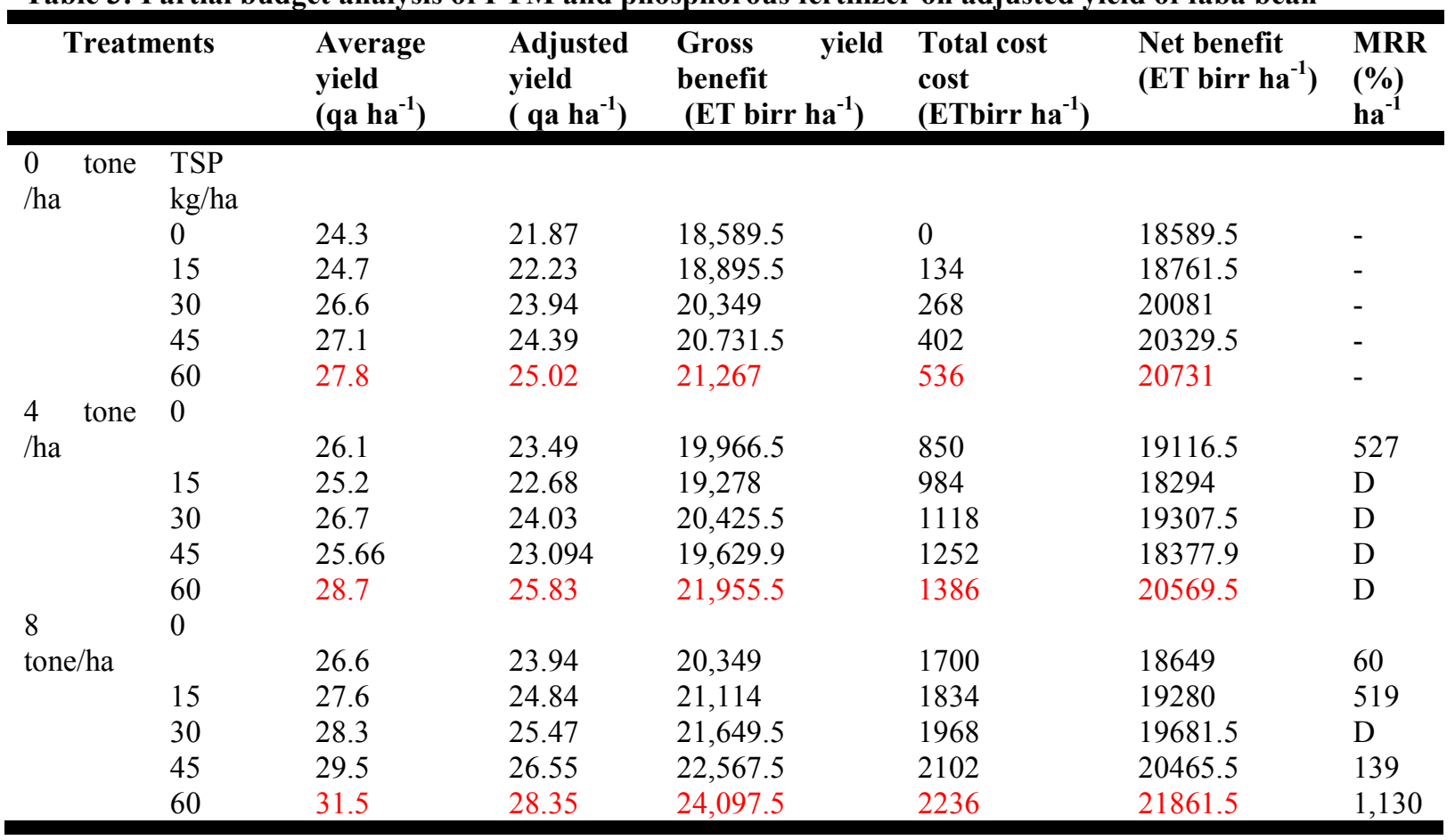

Equivalent cost for FYM preparation, TSP fertilizer and grain yield were calculated based on the current price (TSP ET birr20 $\mathrm{kg}^{-1}$ FYM birr4.7 $\mathrm{kg}^{-1}$ and yield ET birr $8.50 \mathrm{~kg}^{-1}$ ), D =dominate

According to CIMMYT (1988), after the treatments were arranged in order of increasing total cost that vary, any treatment that has net benefit less than or equal to those of a treatment with lower variable costs is dominated (Table 11). In this experiment, costs input such as TSP and N fertilizer, management costs like agronomic management and harvesting cost were considered. The study realized all treatments and $\mathrm{N}$ fertilizer as reference treatment. Our work has Shown that, the maximum net benefit gained from almost all combination with 4 and 8 tone ha and $60 \mathrm{~kg}$-ha TSP respectively, however, the observed benefits due to the treatments can 
still somehow increased the income. CIMMYT (1988) reported dominated treatments have a lower extra gross margin per unit of extra costs than other treatments. Therefore, can be eliminated from further consideration in marginal analysis, because of the increase in yield of such treatment is not adequate to compensate the increase in cost.

\section{CONCLUSION AND RECOMMENDATION}

The study was conducted with the aim of evaluating the effects of P fertilizer with FYM on growth of Faba bean. As Ethiopia is an agricultural country, its development is strongly linked with the agricultural resource base. The study areas soil physical parameters (particle size distribution, water holding capacity, bulk density and soil porosity) were analyzed to check the soil aeration, water movement, plant root penetration, microbial movement As the soil analysis result showed in both Tembaro sites, the soils of the study area in both sites were very ideal soil for crop production including faba bean with good aeration, water holding capacity, root ability(no compaction) and microbial activities.

The soil chemical parameters analysis were occurred before crop sowing and after harvesting for $\mathrm{pH}, \mathrm{OM}$, av.P, TN and CEC in both Tembaro site. The soil in both sites as $\mathrm{pH}$ value showed strongly acidic and after application of FYM modified into moderately acidic. After harvesting except TN all parameters showed that increasing pattern that revealed that the application of FYM modified the soil fertility states and solving the soil acidity problem with increasing the soil crop productivity. Farm yard manure the nutrient content level was tested in laboratory for $\mathrm{pH}, \mathrm{OM}$, av.P, TN and CEC. The farm yard manure was used in both sites were the same.

Days 50\% emergence, Days $50 \%$ flowering, plant height per plant, Days to physiological matutity, Tillers per plant, number of pods per plants, seeds per pods, total biomass yield, grain yield and 100 seed wieght were divulged that significant difference among control treatments' and FYM and TSP applied treatments'. As the data showed that increasing pattern of biological yield, grain yield as well as economic yield in almost all replications systematically from control treatment to 8 tone ha-1 FYM and $60 \mathrm{~kg}$ ha-1 TSP applied parts in both Tembaro.

The economic analysis in this study, costs input such as TSP and N fertilizer, management costs like agronomic management and harvesting cost were considered. The study realized all treatments and $\mathrm{N}$ fertilizer as reference treatment. Our work has Shown that, the maximum net benefit gained from almost all combination with 4 and 8 tone ha and 60kg-ha TSP respectively, however, the observed benefits due to the treatments can still somehow increased the income.

Based on this study finding, some specific recommendations are forwarded as follows:

$>$ Applying farm yard manure increasing the soil fertility by increasing soil chemical properties such as $\mathrm{PH}$ value, OM, av.P and CEC, modifying the soil physical properties to ideal for agricultural productivity and modifying the soil acidity from strongly acidic to moderately acidic so using FYM should have many functions when applying by following appropriate patterns.

$>$ According to the study result optimum combination rates with 4 and 8 tone ha FYM and $60 \mathrm{~kg}$-ha TSP in both study sites.

$>$ The soil $\mathrm{pH}$ value less than 5.5 in both study sites before cropping, phosphorus availability become limited due to formation of different complexes, applied phosphorus should be required.

\section{REFERENCE}

Amare Ghizaw, Tekalign Mamo, Zewdu Yilma, Adamu Molla and Yeshanew Ashagre. 1999. N and P effect on faba bean yield and some yield components. Journal of Agronomy and crop science 182:167-174.

Berry, P.M., Stockdale, E.A., Sylvester-Bradley, R., Philipps, L., Smith, K.A., Lord, E.I., Watson, C.A., Fortune, S., (2003) N, $P$ and $K$ budgets for crop rotations on nine organic farms in the UK. Soil Use Mgt. 19:112118.

Cadish, G. 1990. Influence of $P$ and $K$ on growth and symbiotic nitrogen fixation of Centrosema spp. And other tropical forage legumes. PhD thesis, Swiss Federal Institute of Technolgy, Zurich, Switzerland.

Correll, D.L. (1998) The role of phosphorus in the eutrophication of receiving waters: A review. J. Environ. Qual. 27:261-266.

Dodd, J.R. and Mallarino, A.P.(2005) Soil-test phosphorus and crop grain yield responses to long-term phosphorus fertilization for corn-soybean rotations. Soil Sci. Soc. Amer. J. 69:1118-1128.

Elmaz, O., Cerit, H., Ozcelik, M., Ulas, S., (2004) Impact of organic agriculture on the environment. Fresenius Environ. Bul. 13:1072-1078.

Gosling, P., Shepherd, M. (2005) Long-term changes in soil fertility in organic arable farming systems in England, with particular reference to phosphorus and potassium. Agr. Ecosystems Environ. 105:425-432.

Havlin, J.L., Beaton, J.D., Tisdale, S.L., Nelson, W.L. (2004) Soil fertility and fertilizers: An introduction to nutrient management (Prentice-Hall, Upper Saddle River, NJ), 7th ed.

Horst, W.J., Kamh, M., Jibrin, J.M., Chude, V.O. (2001) Agronomic measures for increasing P availability to 
crops. Plant Soil 237:211-223.

Newman, E.I. (1997) Phosphorus balance of contrasting farming systems, past and present. Can food production be sustainable? J. Appl. Ecol. 34:1334-1347.

Stockdale, E.A., Lampkin, N.H., Hovi, M., Keatinge, R., Lennartsson, E.K.M., Macdonald, D.W., Padel, S., Tattersall, F.H., Wolfe, M.S., Watson, C.A. (2001) Agronomic and environmental implications of organic farming systems. Adv. Agron. 70:261-327.

Stockdale, E.A., Shepherd, M.A., Fortune, S., Cuttle, S.P. (2002) Soil fertility in organic farming systemsFundamentally different? Soil Use Mgt. 18:301-308.

Watson, C.A., Atkinson, D., Gosling, P., Jackson, L.R., Rayns, F.W. (2002a) Managing soil fertility in organic farming systems. Soil Use Mgt. 18:239-247.

Watson, C.A., Bengtsson, H., Ebbesvik, M., Loes, A.-K., Myrbeck, A., Salomon, E., Schroder, J., Stockdale, E.A. (2002b) A review of farm-scale nutrient budgets for organic farms as a tool for management of soil fertility. Soil Use Mgt. 18:264-273.

Nelson, L. David; Cox, M. Michael. 2005. "Chapter 14- Glycolysis, Gluconeogenesis, and the Pentose Phosphate Pathway” in Principles of Biochemistry. Freeman, New York. p. 551.

Vered, Y; Grosskopf, I; Palevitch, D; Harsat, A; Charach, G; Weintraub, MS; Graff, E (1997). "The influence of Vicia faba (broad bean) seedlings on urinary sodium excretion". Planta medica 63 (3): 237-40. doi:10.1055/s-2006-957661. PMID 9225606. 